\author{
Renata Rettinger \\ Zakład Geografii Regionalnej \\ Instytut Geografii \\ Akademia Pedagogiczna w Krakowie
}

\title{
Gospodarstwa farmerskie jako forma aktywizacji gospodarczej obwodu lwowskiego
}

Uzyskanie przez Ukrainę niezależności politycznej zapoczątkowało trudny okres przebudowy jej struktury ekonomicznej i unowocześniania większości sfer życia społeczno-gospodarczego. Warunki, w jakich dokonują się zmiany, są jednak bardzo skomplikowane. Kraj stanowił wcześniej część ZSRR, w ramach którego spełniał określone funkcje gospodarcze i był silnie zespolony więzami produkcyjnymi z całą gospodarką radziecką. Gwałtowne zerwanie tych powiązań w wyniku rozpadu ZSRR doprowadziło do powstania wielu ograniczeń normalnego funkcjonowania państwa i spowodowało konieczność restrukturyzacji jego gospodarki. Największe problemy pojawiły się w przedsiębiorstwach przemysłowych kooperujących w okresie istnienia ZSRR $\mathrm{z}$ wieloma fabrykami, rozsianymi nieraz po całym kraju. Nieprzypadkowo więc $\mathrm{w}$ tych dziedzinach gospodarki Ukrainy regres jest największy i zmiany restrukturyzacyjne są mało widoczne.

Szczególnie skomplikowana sytuacja występuje w ukraińskim rolnictwie, które w ciągu zaledwie kilku ostatnich lat drastycznie ograniczyło produkcję roślinną oraz hodowlę, co stało się przyczyną poważnych problemów ogólnonarodowych związanych z dostawą produktów żywnościowych na rynek wewnętrzny i na eksport.

Tymczasem doświadczenia państw Europy Środkowej dowodzą że dla początkowego okresu przechodzenia od gospodarki centralnie sterowanej do gospodarki rynkowej niezmiernie istotne jest uzyskanie w miarę stabilnej sytuacji w zakresie zaopatrzenia kraju w podstawowe artykuły żywnościowe. W tych krajach, podobnie jak na Ukrainie, wydatki na żywność pochłaniają bowiem około $50 \%$ ogółu wydatków, a w rodzinach o niskich dochodach - nawet $75 \%$. Sukcesy w budowie nowych struktur gospodarczych w Polsce, Czechach i na Węgrzech są w znacznym stopniu związane z relatywnie korzystną sytuacją w rolnictwie, dzięki której własna produkcja zaspokaja potrzeby żywnościowe i stanowi ważny produkt eksportowy. W stosunku do tych krajów sytuacja w rolnictwie Ukrainy, podobnie zresztąjak i Rosji, jest o wiele mniej korzystna. Potrzebne są zdecydowane reformy ustrojowe i strukturalne w samym rolnictwie oraz w innych ogniwach gospodarki żywnościowej.

Jednak zarówno uwarunkowania zewnętrzne, jak i wewnętrzne takich zmian są bardzo skomplikowane, nie udało się bowiem skutecznie ograniczyć trwającego od $1991 \mathrm{r}$. kryzysu, który negatywnie wpływa na rolnictwo Ukrainy i praktycznie uniemożliwia restrukturyzację kolektywnych gospodarstw, stanowiąca podstawowy warunek szerszych zmian w gospodarce kraju. Kryzys doprowadził do zasadniczej zmiany sposobu gospodarowania w rolnictwie. Rozpad ZSRR stworzył zupełnie nową sytuację dla ukraińskiego rolnictwa zarówno pod względem funkcji produkcyjnych, jak i warunków techniczno-ekonomicznych i społecznych, w jakich rolnicze przedsiębiorstwa muszą działać. Gwałtowny wzrost inflacji sparaliżował działalność inwestycyjną oraz proces odradzania technologicznego i strukturalnego gospodarstw rolnych. 
W ocenach dotychczasowych zmian na Ukrainie zwraca się uwagę na to, że istniejący kryzys gospodarczy odzwierciedla się w największym stopniu w rolnictwie, a przeprowadzone reformy nie wpływają aktywizująco na gospodarstwa rolne. Temu kryzysowi można nawet przypisać znaczny wpływ na produkcję rolniczą, skutkujący jej spadkiem. Spadek jest największy spośród wszystkich krajów byłego ZSRR i dotyczy wszystkich podstawowych dziedzin rolnictwa. W latach 1990-2000 zbiory zbóż na Ukrainie spadły z prawie $48 \mathrm{mln}$ ton do niewiele ponad $23 \mathrm{mln}$ ton, tzn. o ponad $52 \%$, a przeciętne plony o $47 \%$, do $19,3 \mathrm{~g} / \mathrm{ha}$, tzn. do poziomu, który notowano w tym kraju na początku lat 60 . XX w. Wtedy jednak tutejsze rolnictwo znajdowało się w stadium powojennej odbudowy, zużywało niewiele nawozów i środków ochrony roślin, było bardzo słabo zmechanizowane. W 2005 r. zanotowano stosunkowo wysokie zbiory $-37 \mathrm{mln}$ ton, co było spowodowane bardzo dobrymi warunkami pogodowymi w tym roku. Spośród pozostałych roślin zwiększyły się jedynie zbiory ziemniaków (o 33\%) oraz kukurydzy (o 108\%). Spadek produkcji zbóż spowodował ogromny regres w hodowli, zwłaszcza trzody chlewnej, owiec i drobiu. Zwierzęta należały w dużej części do gospodarstw przyzagrodowych. Hodowano je, wykorzystując do tego celu chleb kupowany po bardzo niskich cenach. W 2005 r. hodowano na Ukrainie zaledwie 6,4 mln sztuk trzody chlewnej (w 1990 r. około $20 \mathrm{mln}$ - spadek o 68\%). Podobna sytuacja powstała hodowli bydła: w 1990 r. hodowano 24,6 mln sztuk, a w 2005 r. 6,9 mln sztuk (spadek o 72\%).

\section{Prawne podstawy rozwoju gospodarstw farmerskich na Ukrainie}

Od momentu uzyskania niepodległości, w gospodarce Ukrainy widoczny jest brak konsekwentnie realizowanych reform gospodarczych. Połowiczne i jedynie deklarowane reformy dotyczą także rolnictwa ukraińskiego, w którym dokonano powierzchownej restrukturyzacji kolektywnych gospodarstw rolnych (Grykień 2006). Podstawowym problemem jest brak regulacji prawnych, który ogranicza w znacznym stopniu powstawanie nowych form gospodarowania ziemia, a przede wszystkim stanowi barierę dla funkcjonowania oficjalnego rynku ziemi.

Aktualna struktura agrarna jest wynikiem wprowadzenia w grudniu 1999 r. Dekretu Prezydenta Ukrainy „O potrzebie zastosowania natychmiastowych zabiegów w celu przyspieszenia reform w rolnictwie". Zgodnie z tym dokumentem nastapiły istotne zmiany typu społeczno-gospodarczego i organizacyjnego. Ważny krok zrobiono w kierunku sformowania nowej struktury organizacyjnej sektora rolnego. Obecnie niemal wszystkie podmioty prowadzące działalność gospodarczą w rolnictwie tworzone są na zasadach prywatnej własności ziemi i innych środków produkcji, m.in. towarzystwa gospodarcze, rolnicze spółdzielnie produkcyjne, przedsiębiorstwa prywatne dzierżawiące ziemię. Dekret umożliwił wydzielenie - z jednolitego obszaru - części ziemi grupom właścicieli w celu organizacji wspólnego zagospodarowania, przekazania go w dzierżawę lub zagospodarowania w inny sposób (na przykład sprzedaży). $Z$ dekretu wynika także rozporządzenie, że ,podczas zawierania umowy o dzierżawie ziemi, podstawą prawną jest certyfikat dający prawo do własności ziemi. Jest on dokumentem, który potwierdza prawo dzierżawcy do zarządzania, korzystania i rozporządzania wyznaczonym kawałkiem ziemi”. Dzięki tym przepisom umożliwiono tworzenie działek ziemskich o nowych strukturach, które zostały utworzone na bazie gospodarstw społecznych metodą dzierżawy części ziemi, bez konieczności ich parcelowania.

W 1991 r. na Ukrainie państwowa własność ziemi stanowiła prawie 100\% użytków rolnych. Konstytucja przewiduje trzy formy własności: prywatną, państwową i komunalną. Podstawy prawne tworzenia gospodarstw farmerskich zostały zawarte w kodeksie rolnym. Nieruchomości rolne niezbędne do prowadzenia gospodarstw farmerskich przekazywane są na własność lub w użytkowanie z gruntów państwowego „zapasu” ziemi. W przypadku kołchozów i sowchozów dawnym pracownikom mogą być przekazywane nieruchomości rolne z areału tych jednostek. Powierzchnia nowo tworzonego gospodarstwa nie powinna przekraczać 50 ha użytków rolnych i 100 ha powierzchni ogólnej 


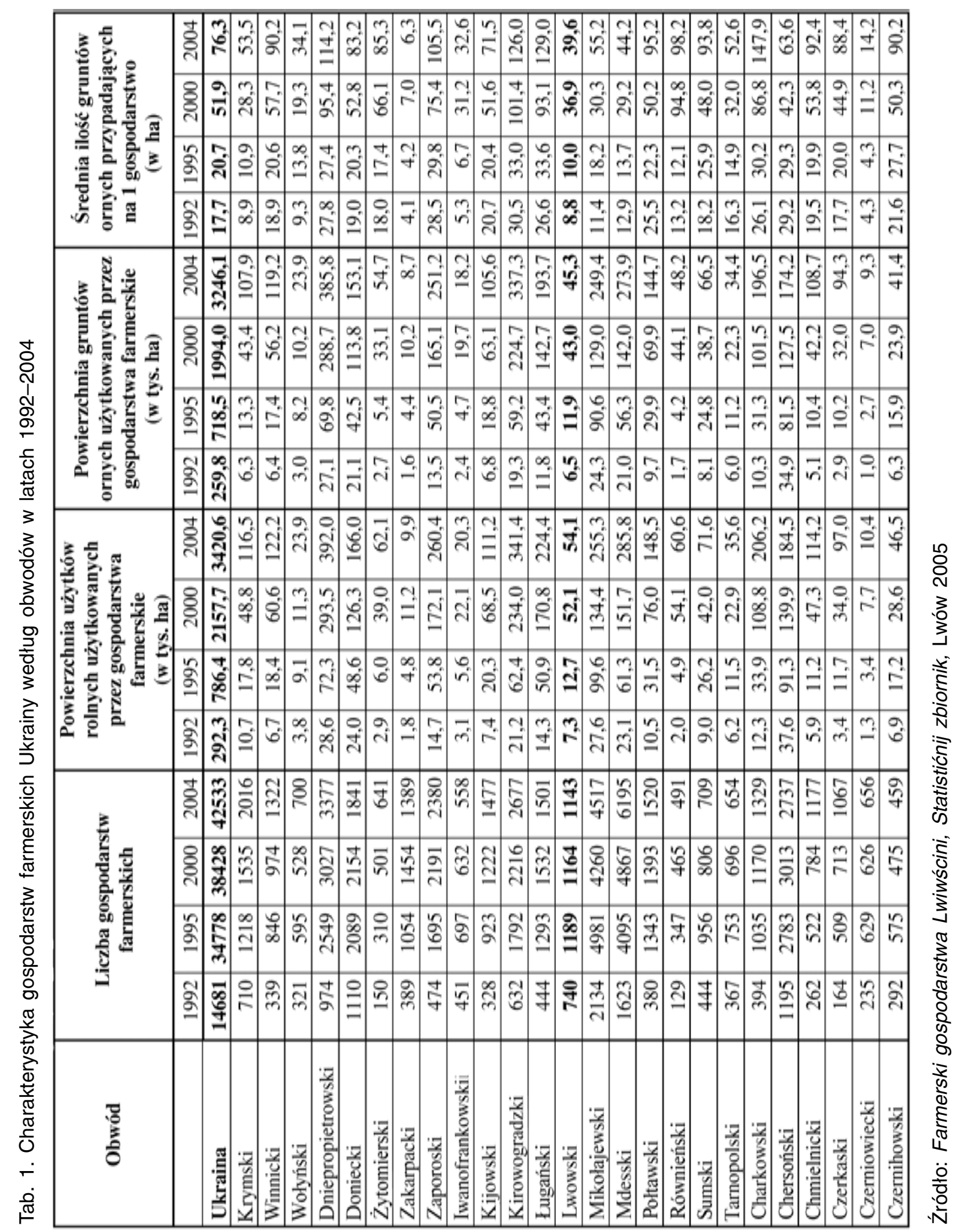


(w tym działka przyzagrodowa). W wielu regionach Ukrainy dopuszczalne są pewne odstępstwa od tej reguły, ponieważ ostateczną wielkość gospodarstwa określają rady rejonowe lub wiejskie po uwzględnieniu regionalnej specyfiki rolnictwa oraz możliwości zagospodarowania ziemi. W skład gruntów gospodarstw farmerskich wchodzą bezpłatne działki, których wielkość jest określana odrębnie dla każdej miejscowości; pozostałą część nabywa się odpłatnie (Grykień 2006).

Prawo do tworzenia gospodarstw farmerskich mają obywatele Ukrainy, którzy ukończyli 18 lat. Pierwszeństwo przysługuje mieszkańcom wsi mającym kwalifikacje do pracy w rolnictwie. W praktyce są to głównie członkowie likwidowanych rolniczych spółdzielni produkcyjnych oraz ich domownicy. Do obowiązków właścicieli należy zarejestrowanie gospodarstwa farmerskiego w radzie. W ten sposób właściciel uzyskuje status osoby prawnej. Nowe gospodarstwa są na okres trzech lat zwolnione od opłaty za ziemię, lecz nie mogą to być gospodarstwa dzielone.

\section{Zmiany w liczbie oraz powierzchni gospodarstw farmerskich}

Proces tworzenia gospodarstw farmerskich na Ukrainie rozpoczął się w $1991 \mathrm{r}$. W pierwszym roku powstało ich 81, a w 1993 r. funkcjonowało już 20 tys. gospodarstw. Obecnie na terytorium Ukrainy zarejestrowanych jest 42,5 tys. gospodarstw farmerskich. Stagnacja w tworzeniu nowych jednostek trwała w drugiej połowie lat 90. XX w. (tab. 1).

Niemal od początku reform obserwuje się znaczne różnice w przestrzennym przebiegu zjawiska prywatyzacji rolnictwa, szczególnie zaś powstawania i rozwoju gospodarstw farmerskich. Najwięcej gospodarstw farmerskich jest w obwodach: odesskim (około 6,2 tys.), mikołajewskim (4,5 tys.) oraz dniepropietrowskim (3,3 tys.). Najmniejszą liczbę gospodarstw tego typu odnotowano w obwodach: czernihowskim, rówieńskim, iwanofrankowskim, czerniowieckim, tarnopolskim i żytomierskim. Jest prawidłowością, że tego typu gospodarstwa nie powstają tak licznie w obwodach charakteryzujących się słabszymi warunkami przyrodniczymi. Należą do nich obszary północnej części kraju (Polesie), zachodniej oraz południowo-zachodniej (Karpaty). W obwodzie lwowskim w 2004 r. funkcjonowały 1143 gospodarstwa farmerskie, a w latach 1995-2004 liczba ta ulegała niewielkim wahaniom (tab. 1).

Gospodarstwa farmerskie otrzymały w użytkowanie 3,4 mln użytków rolnych, z czego 95\% stanowią grunty orne (tab. 1). Ziemie użytkowane przez gospodarstwa farmerskie stanowią zaledwie 8,4\% użytków rolnych i 9,9\% gruntów ornych Ukrainy. Średnia wielkość gospodarstwa farmerskiego w 2004 r. wynosiła 80,4 ha (w 1992 r. około 19,9 ha). Największe gospodarstwa występują we wschodniej i południowo-wschodniej części Ukrainy (strefa stepowa). W obwodzie charkowskim średnia wielkość gospodarstwa to 155,2 ha, w ługańskim - 149,1 ha, w kirowogradzkim - 127,5 ha, w dniepropietrowskim - 116,1 ha. Najmniejsze gospodarstwa powstały w obwodach: zakarpackim - 7,1 ha, czerniowieckim - 15,9 ha, wołyńskim - 34,1 ha, iwanofrankowskim - 36,4 ha. W obwodzie lwowskim średnia wielkość gospodarstwa farmerskiego wynosi 47,3 ha i jest prawie dwukrotnie mniejsza niż średnia krajowa.

Przestrzenne zróżnicowanie liczby i wielkości gospodarstw farmerskich w obwodzie lwowskim przedstawia tab. 2. Największa liczba tych gospodarstw działa w rejonach sokalskim, pustomyckim i żółkiewskim, a najmniejsza w rejonach skolskim i turskim (najdalej na południe wysunięte rejony obwodu lwowskiego). Największe gospodarstwa położone są w rejonach: samborskim (153,7 ha), buskim (92,0 ha), żydaczewskim, sokalskim i stryjskim. Najmniejsze gospodarstwa są charakterystyczne dla rejonów położonych na obszarze Karpat (skolski i turski).

Struktura zasiewów w gospodarstwach farmerskich obwodu lwowskiego przedstawia się następująco: 71,6\% gruntów ornych przeznacza się pod uprawy zbożowe, 16,3\% pod uprawy pastewne, $2,9 \%$ pod buraki cukrowe, $2,5 \%$ pod ziemniaki, $2,1 \%$ pod uprawę $\operatorname{lnu}$, a 1,4\% - pod sady owocowe. W przypadku gospodarstw farmerskich zauważa się specjalizację w zakresie 


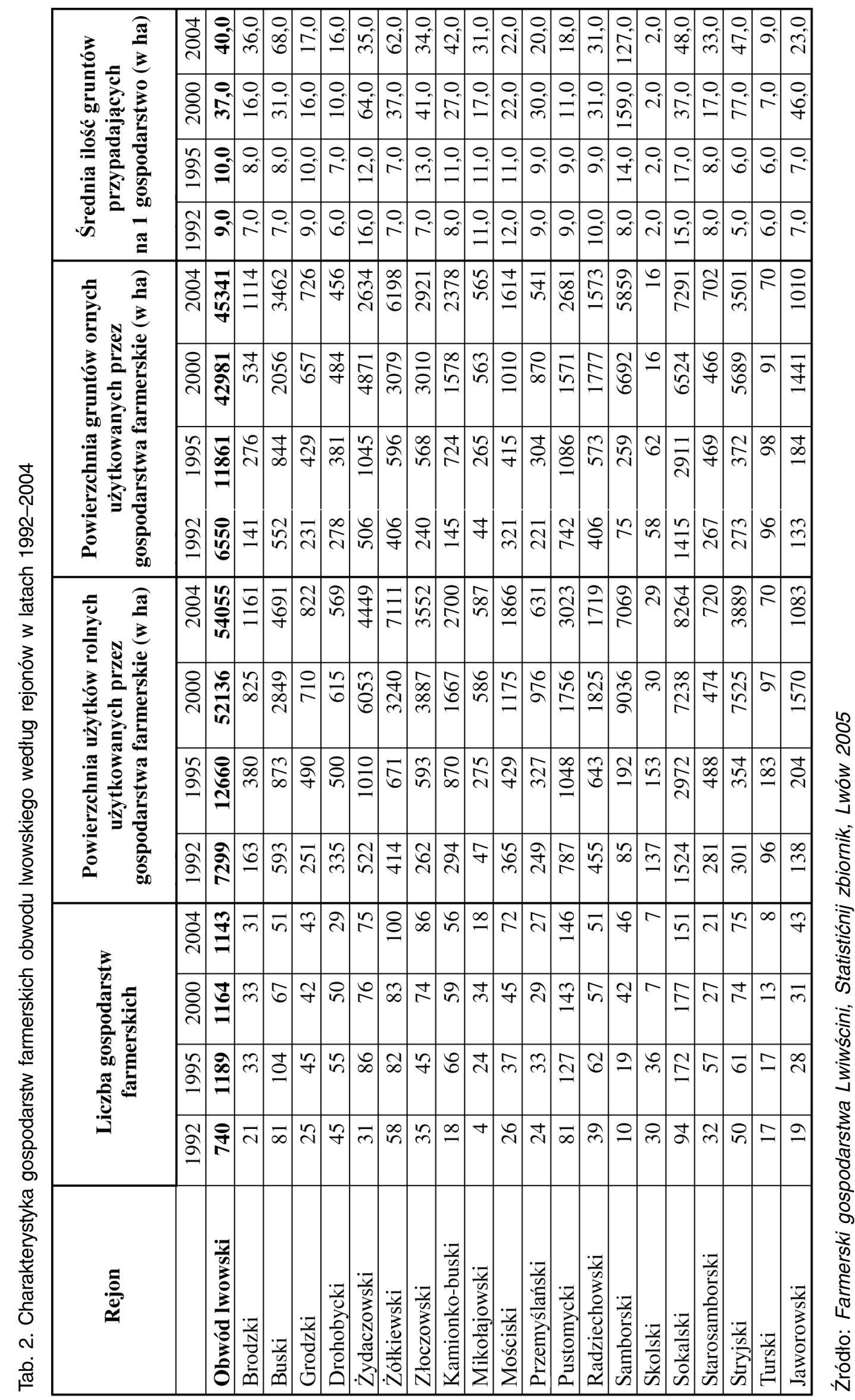


uprawy zbóż, gospodarstwa przyzagrodowe zaś mają bardziej zróżnicowaną strukturę zasiewów: $33,9 \%$ przeznacza się pod uprawę zbóż; $28,9 \%$ pod uprawy pastewne, a 27,3\% pod ziemniaki.

Analizując rolę gospodarstw farmerskich w produkcji rolnej obwodu lwowskiego należy stwierdzić, że od początku lat 90. XX w. obserwuje się tendencję wzrostu w zakresie zarówno produkcji roślinnej, jak i zwierzęcej. Udział gospodarstw farmerskich w zbiorach poszczególnych roślin w obwodzie lwowskim w 2004 r. przedstawia się następująco: zboża 8,5\%, buraki cukrowe 7,7\%, len $40,1 \%$, ziemniaki $0,5 \%$, owoce $1,4 \%$.

Jeszcze mniejszą rolę odgrywają gospodarstwa farmerskie w zakresie produkcji zwierzęcej. Udział w pogłowiu głównych zwierząt gospodarskich jest bardzo niski: bydło 1,3\%, trzoda chlewna $1,8 \%$, owce i kozy $0,7 \%$, drób $1,5 \%$, konie $0,6 \%$.

Należy się zastanowić, dlaczego gospodarstwa farmerskie w zachodniej części Ukrainy, a w szczególności w obwodzie lwowskim, odgrywają tak niewielką rolę zarówno w produkcji roślinnej, jak i zwierzęcej. Wcześniejsza analiza wykazała, że występuje tam stosunkowo niewielka liczba gospodarstw farmerskich. Liczba nowo powstających gospodarstw farmerskich jest w dużej mierze uzależniona od ilości ziemi we władaniu gospodarstw przyzagrodowych w poszczególnych obwodach czy rejonach. W zachodniej części Ukrainy ludność wiejska posiada duże ilości gruntów rolnych użytkowanych w ramach gospodarstw przyzagrodowych, co może świadczyć o jej mniejszym zainteresowaniu tworzeniem od podstaw nowych gospodarstw, a w szczególności gospodarstw farmerskich, które podlegają odrębnym przepisom prawnym i fiskalnym. Drugim ważnym czynnikiem jest zachowanie na tych terenach tradycji chłopskiego gospodarowania na roli w odróżnieniu od obszarów wschodniej części, wcześniej zsowietyzowanej (Grykień 2006).

\section{Podsumowanie}

Na Ukrainie powstawanie indywidualnych gospodarstw rolnych odbywało się poprzez nadawanie pracownikom sowchozów i kołchozów tytułów własności ziemi, które mogły stanowić podstawę indywidualnego gospodarowania. Niestety, skomplikowana sytuacja legislacyjna oraz ekonomiczna spowodowały brak zainteresowania tą forma gospodarowania na obszarach wiejskich.

Znaczenie gospodarstw farmerskich jako nowej formy gospodarowania w rolnictwie jest na Ukrainie niewielkie i niewspółmierne do oczekiwań społeczeństwa. Główną barierą rozwoju jest brak kapitału, infrastruktury gospodarczej, zabudowań gospodarczych oraz środków produkcji (siły pociagowej, maszyn rolniczych, nawozów sztucznych i środków ochrony roślin). Ograniczenia wynikają także z niepewnego klimatu politycznego, częstych zmian w aktach prawnych odnoszących się do własności ziemi, czego skutkiem są poczucie niepewności i brak stabilności. To zaś ogranicza podejmowanie decyzji inwestycyjnych związanych z tworzeniem nowych gospodarstw rolnych - farmerskich.

Zmiany w polityce rolnej kraju powinny doprowadzić do stworzenia na wsi gospodarki wielosystemowej, ukierunkowanej na rzeczywistego właściciela i gospodarza ziemi. Zakres, tempo i jakość reformy rolnej zależą bezpośrednio od doskonalenia stosunków agrarnych. Szczególne znaczenie ma odtworzenie naturalnych związków łączących rolnika z ziemią, czyli właścicielem środków produkcji i konsumentem wypracowanych zysków. Indywidualne gospodarstwa rolne (przyzagrodowe, farmerskie) borykają się z dużymi trudnościami związanymi z niedostatkiem kapitału ograniczającym rozwój mechanizacji i budownictwa gospodarczego, ale także z brakiem pomocy prawnej ułatwiającej ich funkcjonowanie oraz poradnictwa naukowego w zakresie organizowania prywatnej działalności gospodarczej. Równocześnie należy stwierdzić, że w okresie transformacji, w związku z narastającymi problemami, znacznie lepiej radzi sobie sektor prywatny niż uspołeczniony. 


\section{Literatura}

1. Bański J., 1999., Obszary problemowe w rolnictwie Polski., „Prace Geograficzne” 172/1999, IGiPZ PAN, Wrocław

2. Bański J., 2003., Wspótczesne i przyszłe zmiany w strukturze przestrzennej obszarów wiejskich - wybrane zagadnienia., Studia Obszarów Wiejskich PTG, t. IV, Warszawa

3. Grykień S., 2006., Przekształcenia w rolnictwie Europy Środkowo-Wschodniej ze szczególnym uwzględnieniem nowych krajów zwiazkowych Niemiec, Polski i Ukrainy, Studia Geograficzne Uniwersytetu Wrocławskiego, Wrocław

4. Jaworowski P., 2003., Wybrane problemy przedsiębiorczości na obszarach wiejskich [w:] Obszary wiejskie w Polsce a integracja z Uniq Europejska, C. Sobków, M. Zarębski (red.), Wydawnictwo Adam Marszałek, Toruń

5. Kołodziejczak A., 2003., Rola rolnictwa w perspektywie rozwoju społeczno-gospodarczego obszarów wiejskich w Polsce, Studia Obszarów Wiejskich PTG, t. IV, Warszawa

6. Rettinger R., 1998., Rola sektora prywatnego w rolnictwie Ukrainy, Rocznik Naukowo-Dydaktyczny WSP, Prace Geograficzne XVII, Kraków

\section{Farms as a Form of Economic Activation in Lwow District}

The article outlines economic changes in rural areas of Ukraina and especially focuses on the operating new, private farms. Individual farms in Ukraina came into being when workers from sovkhozy and kolkhozy got titles to the lands and were able to the individual farming. Unfortunately they were not interested in this form of farming because of complicated situation in a law and economy. Farms as the new form of agriculture in Ukraina are not important and do not fulfill expectations of the society. Lacks of capital, economic infrastructure, buildings, means of production (tractors, machines, fertilizers, plant pharmaceutics) is the main barrier to the development. Also unsteady political climate and frequent changes in property law are the restrictions that result a sense of incertitude and a lack of stability. Consequently it restricts decisions to investments in new farms. 